\title{
Trademark in the Jordanian Legislations : Its Nature, What Rights Resulted from it, and Its Legal Protection
}

\author{
Dr Mueen Fandi Nhar Alshunnaq \\ Assistant Professor, Faculty of Law \\ Jadara University . Jordan \\ Dr : Farouq Ahmad Faleh Al Azzam \\ Assistant Professor, Faculty of Law \\ Jadara University. Jordan
}

\begin{abstract}
The development of societies and their progress in various fields increase the importance of a trademark where its role appears more in the systems in which the economic freedom of individuals is granted. Innovation and legitimate competition are the basis of economic and commercial progress. They are considered the factors of the economic growth of the state in the presence of a strong and integrated legal system that granted protection for economic projects from the risk of imitation. Trademarks are considered a means of guarantees for both the producer and the consumer at the same time, because it prevents the mixing of certain products with similar products bearing another mark. It also creates confidence in certain products when they bear a reliable mark. Another point is that. Trademarks prevent the appearance of similar goods that are used by other producers to introduce their own products. Additionally ,trademarks play an important role for the manufacturer, trader and service provider as a means of influencing consumers and guaranteeing them to be distinguished from others in the field of dealings. The purpose of this research is to identify the nature of the trademark in the Jordanian legislations to determine its importance, explain the legal protection of the trademark, As well as the rights arising therefrom in accordance with Jordanian legislation.
\end{abstract}

Keywords: Trademark, Civil Protection, Criminal Protection, Jordanian Legislation, Trademark Rights, TRIPS Agreement, Unfair Competition.

\section{Introduction}

The trademark is the most significant components of intellectual property as it plays an important role in the success of commercial projects. It is considered as one of the elements of moral business, that authorizes its owner the right to use it legally. A trademark is also considered as a moral transferred money of economic value. The Jordanian law regulates the provisions of trademarks in a special law. The first was the Trademark Law No. 33 of 1952, but when Jordan joined the World Trade Organization, the Trademarks Law No. 34 of 1999 was issued to comply with the provisions of The Agreement on Trade Related Aspects of Intellectual Property Rights (TRIPS) of 1994.The Jordanian legislator has issued provisions and rules to protect the trademarks, the rights arising therefrom and to limit the infringement thereof, since the subject of trademark infringement is well known and old .

Generally, the importance of the trademark protection and the rights arising therefrom, can be considered through realizing the importance of intellectual property safeguarding, since providing the legal protection for the trademark and the emerging rights lead to the protection of consumers from fraud and falsification of the specifications of the goods.

Therefore, trademark protection is a prerequisite for fair competition regulation and a key factor in the proper economic performance of the market. In addition, it serves the interests of consumers, which provoke the countries to take this issue in their consideration by developing the necessary legislation to protect the trademark, the rights arising therefrom and the commercial interests of the traders. The aim of this research is to protect the rights of trademark owners from the harm caused to them as a result of the trademark infringement. Accordingly, I will address this issue through four topics as follows: in the first topic, the nature of the trademarks. The second topic defines the actions contained in the rights of the trademark, the third topic, explains how to protect the rights arising from the trademark, and in the fourth topic, we address the legal protection of the trademark. 


\section{What is a trademark?}

A trademark is a distinctive sign or symbol that is linked to a consumer's opinion of a specific product or service that has particular specifications that identifies products, goods and services which satisfied him. Their importance and value are steadily increasing. It provides many functions for both the merchant and the service provider . The trademark in Jordan is subject to the Trademark Law No. 33 of 1952, as amended by Law No. 34 of 1999.

\subsection{The concept of trademark and its importance}

According to the Jordanian Trademarks Law No. 34 of 1999 , the trademark is any visually perceptible sign used or to be used by any person for distinguishing his goods or services from those of others. The Jordanian High Court of Justice in its decision No. 49/88 defined it as letters, drawings, marks or a mixture of these items of distinctive and distinguishing character in a form ensures that the goods of the owner are distinguished from the goods of other people.

Through studying the Jordanian definition of the trademark, we find that the legislator gave a specific definition of the trademark in terms of their numbers, types and forms. The legislator did not follow the TRIPS Agreement for example, in the text of Article (15) paragraph (1), which mentioned the forms and elements included in the trademark. This issue has been left to the judge decision ( Ghuwairi, 2008, p.52).

According to TRIPS agreement Article (5) paragraph (1), trademark is "any sign, or any combination of signs, capable of distinguishing the goods or services of one undertaking from those of other undertakings, shall be capable of constituting a trademark. Such signs, in particular words including personal names, letters, numerals, figurative elements and combinations of colours as well as any combination of such signs, shall be eligible for registration as trademarks. Where signs are not inherently capable of distinguishing the relevant goods or services, Members may make registrability depend on distinctiveness acquired through use. Members may require, as a condition of registration, that signs be visually perceptible".

Through the previous definitions of the trademark, it is clear that there is a great importance of the trademark at the international and domestic level, as it is one of the most significant means used by traders to enable consumers to identify their goods and products that carry their brand wherever they exist, and do not mislead them.

This leads to continuous work by producers in improving the quality of their goods to ensure that they compete with their counterparts in the markets. They also determine their source and thus represent the commercial reputation of the manufacturer, trader or service provider in the commercial markets, resulting in continuous pursuit of product development to gain consumer confidence.

Additionally, the trademark is a means of advertising products aims to retain customers and acquire new customers and is also a means to frustrate illegal competition operators (Tabishat, 2009, p.41). It should be noted in this regard that there is various types and forms of trademarks, as stated in Article (7) of the Jordanian Trademarks Law No. (34) of 1999.

The trademark differs from the other elements of intellectual property, especially the distinctive marks, which differ from the trade name that aims to distinguish the commercial project from others of the same nature, while the mark's aim is to distinguish products or services issued by the business, Therefore, the trade name arises at the first use, and the trademark arises at the time of registration and the project holds only one trade name, while the project itself can have multiple marks. The majority of legislation goes to protect the trade name by the rules of unfair competition, while the mark is protected by the rules of imitation.

For this reason, traders tend to register commercial names with marks to ensure better protection, as they can protect them against imitation rules, as well as the rules of unfair competition, unless the name falls as a non-use mark (Abbas, 1971, p. 136), even though The trademark shall not exceed a trade name or include a fictitious, simulated or falsified trade name.

\subsection{Trademark registration and its impact on the right of property}

In the beginning, it must be noted that there are conditions that must be met in order to enjoy the trademark legal protection, the most important of which are the substantive conditions, such as having a distinctive character, seriousness, legality, language and being visually perceptible. It must also meet the formal requirements as stated by Article (7) paragraphs (1) and (2) of the Jordanian Trademarks Law No. 33 of 1952, which is according to Article (11) of the Jordanian Trademark System No. (1) of 1952 and its amendments to follow specific legal procedures for registering a trademark in addition to the persons who have the right to register their trademark as mentioned in the Jordanian Trademarks Law article (6). The reason for the acquisition of trademark rights in different laws differs from the TRIPS Agreement, which did not impose a specific system to acquire this right, but rather harmonized national laws and regulations. 
To maintain a registration of the trademark, some countries require the actual use, such as America .While other countries require the condition of registration such as Morocco .On the other hand, some countries have a mixed system of the former systems, such as the Jordanian law. Where the Jordanian legislator considered the trademark registration as a prescribed decision and considered the certificate registration as an introduction to evidence of the trademark legality in the sense that the registration of the mark and the certificate issued thereon is presumed to prove the ownership of the mark (Tabishat 2009, p. 101).

It can be noted that, according to the Jordanian Trademarks Law No. 33 of 1952, the Jordanian legislator made the basis of the right of the trademark for those who have already used it and not for those who have already registered it, as stipulated in Articles (28).(29), (31) and (32) of the previous law.

The former Articles indicate that the Jordanian law has made the procedure for registration of the mark only as an introduction of a legal evidence on that procedure. This indicates that the effect of the registration is the decision on the right to the trademark only, meaning that the registration of the mark is only a legal presumption of ownership of the mark for the person who registered it .However, this presumption is not conclusive and may be proven contrary. This is what the Jordanian High Court of Justice decided in its decision No. 65/73 of 1973 and resolution No. 169/78 of 1989.( journal of the Bar Association, 1973, p. 1497; and 1989,p899).

It should be noted that the Jordanian legislator did not explicitly require a specific time period that enables the party who claims to be the first-to-use the mark to appeal against the one who has already registered it, which means that the legislator left the door open to prosecute between the party who first-to-use the mark and the one who registered it at any time and however long it takes.

However, the Jordanian judiciary has bridged this legislative gap by applying Article (15) paragraph (1) of the Jordanian Trademarks Law of 1952, as well as Article (25) paragraph (2) of the same law which stipulates that (an application for removal from the register of a trademark on the grounds that there is no justification for its registration according to the provisions of Article 6) 7 or 8 of this law, or on the grounds that the registration of the trademark creates an unfair competition in respect of the applicant's rights in the Hashemite Kingdom of Jordan, must be made within five years as from the registration of the trademark).

This is what the Jordanian judiciary has stressed in through the Supreme Court of Justice resolution No.26/71; 94/79, which stated that (although the registration of the mark is an evidence of ownership of the mark, it is permissible to destroy this presumption by way of reverse evidence, since the user of the former trademark, which has become the trademark of his goods, has the right to cancel the mark registered in the name of another person If the conditions are met) (Journal of the Bar Association,1995, p. 1172 ).

It can be said that the Jordanian judiciary has resolved the question of the period that is necessary to submit a request of defense of the priority of the mark, to challenge those who have registered it, the Jordanian judiciary set the period to five years from the date of registration, if the time limits for registering the mark have expired, the owner of the mark will be the party who registered it and he shall be considered the owner of the mark. We conclude that. The right to ownership of a trademark is a relative rather than an absolute right, and it is a temporary right, not a permanent.

\section{Trademark rights actions:}

There are no significant restrictions on the actions of trademark rights, unlike those of other intellectual property factors this is because the mark is specifically intended for commercial purposes and does not come from intellectual creation, but is chosen from previously existing forms and features that give the product a characteristic which is distinct from others (Khater, 2005, p. 327).

Article (15) of the Jordanian Trademarks Law stipulates that "If the application for the registration of a trademark was accepted and has not been opposed, and the prescribed time for opposition expires, or having been opposed and the opposition has been decided in favor of the applicant, the registrar shall register the said trademark, on receiving payment of the prescribed fee, and unless the application has been accepted in error or unless the court otherwise directs. The trademark shall then be registered as from the date of the application for registration. And the registrar of the application shall be the owner of the trademark that he has registered from the date of the registration.

Article (20) of the Trademark Law specifies the period of registration for 10 years. By the end of this period, the owner of the trademark loses his acquired right unless he renews it, which requires continuing the protection of the trademark to retain it exclusively by its owner and to preserve his rights during this period to use this mark and acting in accordance with the provisions of the law. Accordingly, it is clear from the foregoing that the trademark rights have two main actions: alienable proprietary rights (assignment) and the transferring of interest and the inalienable proprietary rights .In the first Section, we will deal with the act of alienable proprietary rights and its effects, and in the second Section, we will deal with the inalienable proprietary rights. (administrative license of the mark) 


\subsection{Alienable proprietary rights (assignment) and its effect.}

\subsubsection{The legitimacy of the assignment of trademarks}

The acts of trademark assignment can be valid and enforceable if the trademark is registered, but if it is not registered, it is governed by the general rules. For example, if it is attached to a store, it is subject to the rules of transfer of ownership of the store. The rules of unfair competition may be used to regulate the rules of the used trademark provisions. Article (19) No.(2) of the trademark Law stipulated that " The title of a trademark may be transferred, relinquished or mortgaged without transferring the title of the business using the trademark to distinguish his goods or relinquishing or mortgaging it. Seizure of a trademark may also be done independently of the business."

Corresponding to the legal texts, the researcher finds that the Jordanian law permitted the owner of the trademark to transfer his ownership through the sale or assignment.

In case of selling the trademark, the terms of the contract of selling must be met, and the terms of the proper contract must be fulfilled in the Jordanian Civil Code in terms of affirmation, acceptance, situation and reason.

The special conditions stipulated in the Trademark Law shall also be applied in terms of the seller's ownership of the trademark subject of the contract, and the mark shall be properly registered and not mortgaged or seizure for any person, for any reason or related to the right of third parties. In order to regulate the sale of the trademark, it must be registered with the trademark registrar and published in the official newspaper. ( Rashdan 2009, p. 103).

However, if the mark is registered, there are no detailed provisions to regulate the provisions of the transfer of ownership except registration, which is not a condition for its existence, but for its effectiveness against third parties and this is stated by the French Law and Jordanian law. However, the French law stipulated that the transferable act of ownership should be written whether it was a gift or a sale. The mark may be relinquished apart from the store, but, if the latter is completely relinquished, the mark shall be transferred without the need for a specific text, Though, if the store is relinquished with the enumeration of the assigned items and the mark is not mentioned, the mark shall not be transferred with the sold store. If the store is relinquished with its moral elements, the mark shall transfer with the store and the same if the mark is part of a trade name or logo (Keswani, 1998, p. 121).

\subsubsection{The effects of trademark assignments}

The owner of the new mark shall have the right to protect the mark against third parties and shall not be entitled to claim the rights of the mark prior to registration and may refer to the assignee to guarantee the hidden defects and ensure the exposure and entitlement. If the mark is due to others or if third parties object to the primacy of registration of the mark, he could cancel the mark after registering it in accord to the rules of guaranteeing exposure and entitlement.

If the condition of the applicant is three years from the date of the application for registration as in the French law and the Jordanian law and five years in the federal law, the assignee must refrain from any material act that impairs the use of the mark by the assignee. This occurs when a person waives his or her family name or his famous name, He must then take all precautions to prevent any confusion between his products and the products of the assignee, so any use of his name on goods similar to the waiver party, is considered a materially exposure, but if the assignee is a contributor to a company in a trademark, his act is not considered as a waiver of the mark, but is merely a license for the company to use the mark unless otherwise agreed.

\section{2 the inalienable proprietary rights (Trademark License):}

The owner of the mark may not wish to relinquish his ownership, so he licenses the third party to put the mark on his products or services for commercial purposes. The license is one of the applications of the lease, and the terms of the contract must be specified as it is not very different from the lease in terms of its effects. Therefore, we will try in this section to explain how the license contract and its effects are held.

\subsubsection{Licensing Agreement:}

The licensing agreement is not different from the lease, and it is done on a legal ground. The owner may sell his mark to a third party . Licensing agreements usually cover the some basic points, including exclusivity or territorial restrictions, that means the licensee may use the mark only in a particular country, for example, and its use may not be specified in a certain area within the state, because this limits the process of commercial trading within countries. The concept of the state in France has extended to all the countries of the European Union, since the owner may not restrict the licensee's right to use the mark in a country of the European Union (Jallad, 2006, p. 93).

Article (25) of the Jordanian trademark Law for the year 1952 amended for the year 2007 stipulated that the license contract for the use of a trademark shall be in writing and shall be registered. 
This condition is for proof and not for the convening, the person who claims the right the ownership of the mark has to prove it in writing and in the manner that was specified by law. It should be noted that the license contract for the use of the trademark does not affect the ownership of the trademark, it remains owned by the owner but the right to use by the licensee is for a certain period and for a particular fee which is much like the lease contract according to some jurisprudence (Zine El Din, 2009, p. 219).

\subsubsection{The effect of the inalienable proprietary rights ( Licensing Agreement)}

There are some obligations binding on the licensor and other obligations are the responsibility of the licensee as follows:

1- Obligations of Licensor:

The Licensor maintains the power of the license and the right to use it unless the agreement expressly provides otherwise. If the license is monopolistic, the owner may not use the mark unless otherwise agreed. The owner shall guarantee the exposure and maturity and shall be obliged to renew the deposit at the end of the period of protection. He may be exempted from liability if he proves his good intention. The owner may require publicity and marketing of his brand.

In the event of non-compliance of the licensee, the owner may demand the termination of the contract and the latter may place at the disposal of the licensee all his distinctive marks such as trade name, logos and technical knowledge to record the marketing of the products and services subject to the mark (Fawzan, 2012,p.175).

2- Licensee Obligations:

The most important obligation of a licensee is to use the mark. If he did not use it, the owner would demand the cancellation of the contract. The licensee must comply with the terms of the license. If he exceeds it, he shall hold the responsibility of the counterfeiting. If he used it in goods and services that are not specified in the agreement, his work is considered counterfeiting and a breach of contract at the same time, The licensee must comply with the terms of the license and he may not assign the mark to third parties without the consent of the owner. The licensee shall not have the right to file the counterfeiting case unless the agreement otherwise provides that the licensee in this case shall be the agent of the owner by the asset of the law.

If the licensor refuses to grant this right, the licensee shall refer to it by merit or exposure guarantee or entering into an indirect claim against third parties or resorting to the unfair competition case. The French court has accepted such a case.

According to Articles (2), (5) and 617 of the French Act of 2014. The French law authorizes the licensee to enter the case of imitation filed by the owner against the imitator as he has the right to compensation for the damage he suffered from.

\section{Protection of trademark rights:}

The violence on the brand is a prominent phenomenon in the commercial and economic environment thus, legal rules attempt to put strict controls against them, but they remain limited to the proliferation of trademarks internationally, as they need to activate the rules of protection at the international level.

The TRIPS Agreement of 1994, Article (32) sets effective procedural controls for States to protect intellectual property rights, including the trademark. However, the well - known brands representing high-quality goods and services such as perfumes, watches, clothing, videos and computer software are still subject to counterfeiting and infringement which in turn causes a loss to the owner of the mark and shake the confidence of the public of this brand.

\subsection{Determine the scope of the infringement on the brand}

Not every infringement on the brand is a punishable by the law as there are some infringement that are not recognized by the law of the trademark, as imitating the brand may take multiple images of fraud. It may come in form of an identical transfer of the mark so that the counterfeit tag becomes a copy of the real mark.

Imitation is the process of making a mark similar to the whole real mark so that it is difficult for the ordinary consumer to distinguish between them, so it differs from the counterfeit in that the actor does not convey the whole real mark but is keen to make some modifications to them while retaining its general appearance as a slight change in color or in the size of letters and other methods of cheating which leaves his discretion to specialist judge. The French judiciary distinguishes between the infringement on the mark itself by copying or imitating and the use of the mark on goods and services similar to the actual one. Copying the mark is considered imitation if it leads to confusion among the public . 
The French judiciary differentiates between the production of the same mark and the use of the mark on goods and services, as mentioned the act of imitation will not be taken into account unless the mark is fully registered because doing so is not an evidence against others, but if it is registered despite the objection to any infringement is considered an imitation.

Although comparative legislation has indicated that the term of protection is effective from the date of submission of the application, this provision is related to the identification of ownership of the mark for enforcement against third parties.And any infringement against it prior to registration is not an imitation and the claim of imitation is dismissed. The owner of the mark may file a claim for compensation in accordance with the rules of unfair competition if he proves that he has used the mark normally.

However, if the infringement continues after registration, the work is considered an imitation, and it is exempted from the requirement to deposit the famous mark. If it is infringement in the state of protection, although it is not recorded, It shall be prevented, in fact, that its owner cannot file a counterfeiting case if it is not registered in the State of protection but rather he must demand to abrogate any famous mark of the brand that is registered in the name of third parties to be sued and he cannot claim compensation according to the claim of imitation, Therefore, we find that the comparative legislation did not mention the imitation of the famous brand, but focused on the deletion of any sign that constitutes an infringement on the famous mark.

This is important in preventing recourse to a counterfeiting case involving severe penal or civil penalties in relation to a claim for compensation under the rules of responsibility for the wrongful act.

Its procedures are completely different from those of imitation, but imitation cannot be an illegitimate mark even if it is registered. If the defendant is able to prove its illegality, the case of imitation shall be dismissed. The imitation shall be on a registered mark in the State of protection. If it is not registered, he shall not object to the imitation. Articles (2 -.3) of the TRIPS Convention indicate the possibility of protecting any mark registered in any State of the Convention without requiring its registration in the State of protection, but the States parties to the Convention have not amended their provisions as referred to in the Convention.

\subsection{Forms of infringement ( imitation):}

In the light of this comparative legislation, infringement can be limited to five forms: the production, copying, use, pasting or erasure of the mark, all of which are carried out without the consent of the owner of the mark.

\section{Legal protection of the trademark}

This topic will be divided into three sections. In the first section, we will address the civil protection of the trademark, the second section the protection of the trademark in the light of trademark law, and the third section the protection of the trademark in light of the law of unfair competition. In the fourth section the criminal protection of the trademark.

\subsection{Civil protection of the trademark}

The owner of a trademark who has been subject to infringement by others through falsifying or counterfeiting his brand, placing it on competing products or in any form of infringement on the trademark and its rights in a way that leads to confusion among customers about products and goods, has the right to claim the court for preventing this excess or raising confusion in order to avoid hurting the owner of the trademark, the plaintiff may seek compensation for the damage caused by counterfeiting and illegal means. So, we will address in this section the civil protection and the preventive procedures and precaution .

The owner of the trademark rights enjoys civil protection in accordance with the general rules of liability for the wrongful act.

The Jordanian law did not require wrongdoing for tort liability, but only that the act is harmful, causing damage in itself, as defined in Article (256) of the Jordanian Civil Code. The mistake that is made for tort liability is the deviation in the conduct, either negligence, omission or intentional and caused damage to others.

Therefore, a trader who competes must pay compensation for damage caused to the other trader and regardless of whether if his action resulted by a mistake or not, because Article (256) has taken the substantive responsibility of the torturer without considering the activity, whether it is a mistake or not. Article (34) No.(1) of the Jordanian Trademarks Law No. 33 of 1952 and amended by Law No. 34 of 1999 stipulated that "No person shall have the right to file a lawsuit to claim damages for any infringement upon a trademark not registered in the Kingdom".

Accordingly, It is clear from this legal provision that the Jordanian legislator has granted the trademark owner registered in Jordan a legal registration in accordance with the provisions of the Trademark Law, whereby he is entitled to claim compensation for the damage caused by the infringement of his trademark. 
And it denied any right of the trademark if it is not registered. As it is a special law aiming to protect the registered trademark and not to depart from the general rules of civil liability (Zinedine, 2000, p. 394).

According to Article (363) of the Jordanian Civil Code, it is limited to compensation for the actual damage that is actually caused to the creditor without the loss of profits by saying, "If the guarantee is not determined by law or contract a court shall determine compensate for damages caused under contractual liability at the actual value of such damage when it occurred“.

The Jordanian legislator stipulated that to protect the trademark, it should be registered in accordance with the provisions of the law.

The civil protection of the trademarks comes into two forms: trademark protection in trademark law and trademark protection in the law of unfair competition.

\subsection{Trademark protection in the light of the Jordanian Trademark Law}

Article (33) of the Trademark Law No. 33 of 1952 and its amendments stipulates that " 1 - No person may institute any proceedings to claim damages for infringement of a trademark not registered in the Hashemite Kingdom of Jordan; but a person may institute proceedings to annul the registration of a trademark registered in the Hashemite Kingdom of Jordan by a person who is not the proprietor thereof;, after such a trademark has been registered abroad, if the grounds of his claim are those stated in paragraphs $6,7,10$ and 12 of Article (8) of this law. 2- The decision issued by the Registrar may be appealed under this law to the High Court of Justice within two years of its notification date. "

In accordance to the two previous Articles it is clear that the Jordanian law prohibits the ownership of an unregistered trademark from the only means in which it can be relied upon, namely, the legal action to claim compensation for the infringement on that unregistered trademark.

Article (34) of the Trademark Law of 1952 also required the registration of the trademark in Jordan for the benefit of compensation in the event of infringement. This registration remained required despite the promulgation of the Law amending the Trademark Law of 1999 which was issued to comply with the provisions of the TRIPS Agreement. The reason for the requirement of registration is to protect and encourage the owner of the mark to register his trademark and also to defend his right to seek compensation for infringement in the event of violation and not to mislead consumers.

The Jordanian legislator granted the right to compensation resulting from infringement of the registered trademark only and left the trademark that is not registered in the trademark register without civil protection, which is compensation.

\subsection{Protecting the trademark in the light of Jordanian unfair competition law}

The Jordanian legislator defined illegal competition in the Law on Unfair Competition and Trade Secrets No. 15 of 2000 in Article (2) paragraph (A) as (An act of unfair competition shall be deemed to be any competition that interferes with honest competition in industrial or commercial affairs). This definition was used in the Paris Convention for the Protection of Industrial Property against illegal competition, as defined in the Model Law of the Arab States in Article (33), paragraph (1): "Any act of competition that is contrary to honest customs in industrial and commercial transactions shall be deemed illegal."( Sibai, 1986, p. 347).

By studying the definition of illegal competition, we find that the unfair competition is those related to the trademark used in Jordan, whether registered or unregistered in Jordan, as long as it leads to mislead the public and harms. The offended trademark owner was given the right to claim compensation on the basis of the wrongful competition claim, this law exceeded the requirement of registration and it became possible to claim compensation even though it is not registered in Jordan. This is provided for in Article (2) of the Law on Unfair Competition and Trade Secrets No. 15 of 2000. The Jordanian legislator equalized in the protection between the registered trademarks in Jordan and the unregistered one, but it required several conditions which are: the mark should be used in Jordan. The competition mislead the public and that it should be related to the imitation of a trademark that cause confusion with the establishment of one of the competitors, his products or his industrial and commercial activity, where the law permits each interested party the right to initiate a lawsuit provided that the legal interest exists at the time of filing the lawsuit and continue until the dismissal, as provided for in Article (3) paragraph (A) of the Law on unfair competition and secrets No. 15 of 2000 "Any interested party shall be entitled to compensation for any damage caused as a result of any unlawful competition. Which is contrary to the Trademark Law, which limited the right to bring a claim to the owner of the trademark only.

It can be said that the civil protection of the trademark in the law of unfair competition is based on the general rules of civil liability in the Civil Code, which is performed when the offender has discharged a prescribed obligation and the damage has been caused to the third party therefore, he becomes liable to the victim and is obliged to compensate him for the damage he suffered. 
The injured person alone shall have the right to claim compensation. This right shall be regarded as a purely civil right based on the basis of the harmful act based on Article (256) of the Jordanian Civil Code which provides that "every injurious act shall render the person who commits it liable for damages even if he is a non-discerning person."

\subsection{Penal protection of the trademark.}

The penal protection of a trademark is limited to the registered trademark only, there is no penal protection against the unregistered trademark, and it is limited in terms of time and place.

The scope of protection in terms of time is not protected except during the period of registration, which is 10 years or at the stage of renewal, but in terms of place, it is limited to the territory of the State in where the trademark was registered without prejudice to international conventions and treaties, further more, the penal protection does not preclude to claim for the personal right.

It should be noted that Article (41) paragraph (1) of the Trademark Law provides that (If the Kingdom is bound by a bilateral agreement or is a member to an international convention which grants a reciprocal protection to the trademarks registered with any of them, then any national of the state member to the agreement or convention may file an application to the registrar to protect his trademark. Also, he shall have the priority right to those who filed prior applications in the Kingdom for that trademark.).

Article (20) paragraph (a) of the law states that criminal protection is limited to the period of ownership of the trademark, which is 10 years from the date of its registration and may be renewed on the basis of article (21) paragraph (2). If it is not renewed, the registrar may remove it from the register and then it loses the legal protection. In terms of location, it is limited to the territory of the country where the trademark is registered and there is no protection for a registered trademark outside Jordan.

The Jordanian Trademarks Law stated in Article (37) that:

1-Whoever committed with the intention to cheat any of the following deeds shall be penalized by an imprisonment term of no less than three months and no more than one year, or a fine of no less than 100 Jordanian Dinars and of no more than 3000 Jordanian Dinars or by those two penalties:

- Whoever counterfeited a trademark registered under this law, imitated it in any other way that misleads the public, or affixed a counterfeit or imitation mark on the same goods for which the trademark has been registered.

- Whoever illegally used a trademark owned by another on the same class of goods or services for which that trademark is registered.

- Whoever sold or possessed for the purpose of selling or offered for sale goods bearing a trademark whose use is regarded as an offense under paragraphs (A) and (B) of this Article if he was cognizant of that beforehand

3- The provisions of paragraph 1 of this Article shall apply to whoever started to commit any of those acts provided for in this Article or aided or abetted another to commit it.

Article (33) of the same Law stipulated that « Any person who submits a trademark on the grounds that it is registered without being registered shall be liable to a fine not exceeding (50) dinars for each offense).

Article (38) of the Trademark Law has shown that counterfeiting is considered a violation if it is done on a registered trademark.

\section{Conclusion:}

In conclusion this research dealt with the trademark, its importance to the parties, the means of protecting it in accordance with Jordanian legislation and the protection of the rights arising from it being exposed to the risks of counterfeiting and imitation.

In addition to the damages that result from it that affecting the interests of owners of marks, the security, health , safety of consumers and the national economy alike. Which made the Jordanian legislator working on the issuance of national legal legislation to protect the safety and security of the economy of the country and prevent infringement of trademarks. The researcher reached through a his research to a number of results.

\subsection{Results:}

1. The trademark represents each sign or logo placed by the merchant on its goods in order to distinguish between them and their similar manufactures, goods and services.

2. Article (33) of the Trademark Law prohibits the application for compensation for any infringement of unregistered trademarks but has allowed civil protection by stopping infringement and isn't continuing it.

3. Article (33) of the Unregistered Trademarks Law excluded civil protection prescribed for all rights in accordance with the general rules of liability but permitted the prosecution of unfair competition, subject to certain conditions: 
a) The objective civil protection mechanisms derive their origins from the rules of tort liability as a public origin through the unfair competition claim, and the contractual liability in the case of whether the mark replaces a contract of waiving as a license contract for example using a trademark.

b) The substantive and formal conditions required for registration of the mark shall be the basis upon which the right of the mark holder is based. In its absence there is no right and the owner of the mark cannot claim it until all the required procedures have been met.

c) The TRIPS Agreement has mainly contributed to the reformulation of many of the trademark legislation in line with the developments in the field of trade.

d) The TRIPS Agreement stipulates the right to file a civil or criminal action against the registered and unregistered trademark, but the Jordanian law only considered the registered trademark in order to urge trademark owners to register their trademarks.

e) The rights of the owner of the mark are property rights, characterized by certain qualities not far from the right of ownership in the general rules and it may be disposed of by all the permissible conduct.

Recommendations:

1. The necessity of amending the Jordanian Trademark Law in a manner consistent with the developments and in accordance with the current commercial activity such as the TRIPS Agreement.

2. The need to regulate the civil protection of trademarks in a framework of a more precise and detailed code through the incorporation of new provisions in the law of trademarks, especially with regard to the license contract of using the trademark to provide more effective protection and how to specify responsibility for violating.

3. We recommend amending the Trademark Law as the current legislation limits only compensation to the registered trademark.

4. A special law should be enacted to protect intellectual property rights in the same way as Arab and international legislation, since these rights are no less important than the other rights.

5. The decline in economic reality requires the legislator to interfere to address it through giving more consideration to the subject of a trademark and rights arising from them. Also, to provide the necessary means to enter the international field and provide international protection for the owners of the brand as they form the backbone of trade.

\section{References:}

Abbas, M, H (1971) The Property, the Commercial Store, Dar al-Nahda al-Arabiya, Egypt.

Fawzan, M, B (2012) The Legal System of Trade and Brand Name, Comparative Study of Arabic Laws, 1, Law and Ijtihad Library, Riyadh.

Ghuwairi,A,H (2008) The Brand and its Protection, I 2, Dar Al-Falah Publishing and Distribution Jordan.

Jallad, W,E (2006) Legal Protection of Trademarks, Commercial Data and Geographical Indications in the Light of the Law on the Protection of Intellectual Property Rights, Iraq.

Khater, N, H(2005) Explanation of the Rules of Intellectual Property, Industrial Property, Comparative Study between Jordanian, Emirati and French Law, United Arab Emirates University, Dar Wael Publishing, 1, Jordan.

Keswani, A (1998) Intellectual Property, What It Means, Its Vocabulary, Ways of Protecting it, Dar Al-Habib for Publishing and Distribution, Jordan, First Printing.

Rashdan, M,A (2009) Trademarks, Dar Al-Masirah Publishing and Distribution, Jordan.

Tabishat, B, M (2009) Legal Protection of Trademarks Under Jordanian and Egyptian Law and International Conventions, II, World Books for Publishing and Distribution, Jordan.

Zine El Din, S (2009) National and International Brand, Dar Al Thaqafa for Publishing and Distribution, Jordan.

\section{Laws, Conventions and Court Judgments:}

Decisions of the Jordanian High Court of Justice.

Jordanian Civil Law No. 43 of 1976.

The French Intellectual Property Act of 2014.

TRIPS Agreement for 1994.

The Jordanian Unfair Competition and Trade Secrets Law No. 15 of 2000.

The Jordanian Trademarks Law No. 33 of 1952 as amended by Law No. 34 of 1999. 